\title{
SKELETAL MUSCLE ANALYSES IN HEALTH AND IN CERTAIN METABOLIC DISORDERS. I. THE METHOD OF ANALYSIS AND THE VALUES IN NORMAL MUSCLE ${ }^{1}$
}

\author{
By BENJAMIN A. BARNES, ESTHER B. GORDON, AND OLIVER COPE
}

\author{
(From the Department of Surgery, Harvard Medical School, and the Massachusetts General \\ Hospital, Boston, Mass.)
}

(Submitted for publication December 12, 1956; accepted April 11, 1957)

Tissue analyses are of special importance in regard to the meager information available today concerning the role of magnesium in disease. Prior investigations of the concentration of serum magnesium have revealed modest fluctuations unassociated with any clear-cut, consistent, clinical syndromes (1-11). Balance studies (12-15) have been hampered by the lack of low magnesium diets with the result that fluctuations in the balance have been obscured by an excessive magnesium intake and excretion. This mineral is located almost exclusively in the cells or in the skeleton, and calculations based on a standard reference (16) for the composition of the body tissues and on a generally accepted partition (17) of the anatomical compartments of the body indicate that of the 2,100 milliequivalents of magnesium present in the adult body 45 per cent are located in the skeleton. Of the remaining 1,150 milliequivalents 98 per cent exist within the cells, and only 2 per cent of the extra-skeletal magnesium are located in the extracellular fluid.

This paper records the application of established methods of tissue analysis in a series of control muscles to determine the normal composition of skeletal muscle and its variations and also records the application of statistical techniques to define the precision of the methods. In a following report (18) a variety of muscle analyses in diseased states are compared with the control data to extend our information concerning the stability of intracellular magnesium. The authors are indebted to the late Professor J. L. Lilienthal and to Professor A. B. Hastings for the fundamental biochemical concepts and to Sir R. A. Fisher for the pertinent statistical techniques upon which these studies are based.

\section{METHOD}

Selection of skeletal muscle. This tissue was selected for analysis because it represents the greatest bulk of

1 The work in this paper was supported by the Office of Naval Research, NR 114-198. protoplasm, because of the accumulated information concerning its composition, and because of its availability at almost any operation.

Definition of the intra-and extracellular spaces: $A$ biochemical dissection. In the absence of an infallible technique for distinguishing between the intracellular phase and extracellular phase we have accepted the chloride space as an approximation of the extracellular space. It is well recognized that in diseased states where chloride ions may penetrate into the muscle fiber cell, the extracellular space will be falsely enlarged. However, the chloride space still remains a most reasonable and practical means of correcting for the extracellular components to permit calculation by difference of the intracellular components. The evidence for the extracellular location of the chloride ion and for the proportionality of its total mass to the extracellular space has been recently reviewed (19).

Bases of reference in expressing the concentrations of the muscle components. In tissue analyses advantages exist in expressing the results in terms of more than one reference base. Changes in the concentrations of the components in relation to one base might not appear in relating the concentrations to another due to a concomitant shift of the second base. Other considerations in the selection of a reference base are the effects of analytical variations in its determination which would cause fluctuations devoid of any biological significance and the natural variation of a reference base which should be as restricted as possible to minimize the confusion this would introduce into the interpretations. These independent characteristics may be assessed by statistical techniques outlined below.

The reference base of intracellular water introduced by Hastings and Eichelberger (20) has been justified by water being the most plentiful constituent of tissues and by the success achieved in unfolding the properties of blood as a physiochemical system approximating a simple aqueous solution. More recently the use of non-collagen nitrogen (NCN), proposed by Lilienthal, Zierler, Folk, Buka, and Riley (21), as a reference base has the advantage of relating the intracellular components to a standard that is independent of any assumptions that the use of the chloride space entails in the calculation of the intracellular water. The non-collagen nitrogen, which is defined as the nitrogen in whole wet muscle fiber soluble in dilute alkali $(0.05 \mathrm{~N})$, is considered to be a measure of the functioning mass of muscle cells. The use of the solubilities of the muscle fibre proteins to separate 
them from the structural proteins of collagen and elastin has been reported by Lowry, Gilligan, and Katersky (22). These two reference bases of intracellular water and noncollagen nitrogen have been selected for the tissue analyses.

The details of the analysis adopted from the method of Lilienthal (21) are presented briefly to indicate any significant departures from the previously published techniques.

Physical preparation of the muscle and alkaline digestion. The samples of human muscle were excised during an operation under spinal or ether anesthesia from the edge of the incision or from the normal muscle of a freshly removed specimen. They were handled expeditiously and were protected against the loss of water by covering with a damp gauze. The samples weighed approximately 6 to 8 grams for a single analytical run, or twice this weight for duplicate runs. At the time of division and weighing of the muscle samples, gross connective tissue and fat were removed. Where duplicate samples were taken, homogeneous strips of muscle were bisected. The sampling error depends only on the gross evaluation of the muscle, and care was taken to diminish this source of variation.

The following portions were set aside:

One gram weighed into a previously tared, glassstoppered Erlenmeyer flask for the determination of the water and fat content $(20)$;

Six grams weighed into a previously tared weighing bottle for subsequent homogenization; and

One gram of muscle fixed in a formalin solution for histological study.

After the muscle had been weighed, the specimen was often frozen and stored pending further analysis. The blood for analysis was obtained just before or just after the excision of the muscle specimen, and a short series of paired determinations revealed no significant alterations in the serum values over this period of time. Infusions were virtually stopped well before obtaining a sample, and blood was not removed from an extremity into which an intravenous solution had been infused.

The largest portion of muscle was homogenized in a lucite Potter-Elvehjem homogenizer. A "pea soup" homogenate in distilled water was transferred to a $50-\mathrm{ml}$. volumetric flask, made up to volume, and designated as the aqueous homogenate.

Aliquots of the aqueous homogenate were treated with 2.5 volumes of dilute alkali to achieve a final concentration of $0.05 \mathrm{~N} \mathrm{NaOH}$ or $0.05 \mathrm{~N} \mathrm{KOH}$. These sodium and potassium alkaline digests stood at room temperature for 18 hours prior to centrifugation.

The digests were centrifuged for one hour in the cold at a temperature of $4^{\circ}$ to $8^{\circ} \mathrm{C}$. Centrifugation under 1,400 to $1,600 \mathrm{G}$ separated three distinct zones-a thin top layer of fat; an intermediate, aqueous solution containing the electrolytes and the non-collagen nitrogen compounds; and a bottom layer consisting of fine, particulate matter containing the insoluble, collagenous structural proteins. The middle layer was removed by pipette and designated as the sodium or potassium non-collagen nitrogen $(N C N)$ solution. The separation of the fat from the NCN solution after approximately a twentyfold dilution did not significantly alter the concentrations of the other components in the supernatant since the relative amount of fat present was reduced to about 1 per cent or less. Furthermore, the separation of the fat at this stage obviated the necessity of making a correction for its possible contribution to the NCN as proposed by others (23).

Chemical analyses. The methods were the same for blood and muscle specimens except for the dilutions employed, and the techniques were essentially those stated in the original publications with minor modifications to conform to the equipment and experience of the laboratory.

(a) Blood: Hematocrit (24), total nitrogen (25), serum sodium (26), serum potassium (26), serum inorganic phosphorus (27), chloride (28), serum magnesium (29), and serum water by drying to constant weight.

(b) Muscle: Aqueous homogenate-Magnesium in quadruplicate. Sodium NCN solution-Nitrogen and potassium in triplicate; phosphorus and chloride in quadruplicate. Potassium NCN solution-Sodium in triplicate.

Calculation of the derived values. The calculations for the derived values are symbolized below starting with the analytical values found and ending with the derived intracellular concentrations of a component expressed as the amount per $100 \mathrm{Gm}$. wet fat-free muscle, per kilogram of intracellular water, and per Gm. of NCN. The corrections for the chloride content and for the nitrogen content of the occluded blood in the muscle samples require preliminary explanation.

The chloride content of the red cells is an appreciable amount of the total chloride in whole muscle if the blood naturally saturating a fresh specimen is not removed by pressure and blotting. Preliminary studies using radioactive iodinated serum albumin compared the specific activity of the peripheral serum and the activity of the muscle sample. For the approximate calculation of the blood volume in the muscle sample it was assumed that the hematocrit in normal muscle was equal to the peripheral hematocrit of 45 per cent. The serum content of muscle was found to be 5 per cent by weight; and therefore, each $100 \mathrm{Gm}$. of muscle contains approximately $5 \mathrm{ml}$. of serum and $4.09 \mathrm{ml}$. of red cells. The correction for the chloride content of the red cells is obtained by multiplying the average red cell volume of $4.09 \mathrm{ml}$. per $100 \mathrm{Gm}$. of muscle by a factor to correct for any departure of the hematocrit from 45 per cent and by the concentration of chloride normally found in red cells $-50 \mathrm{mEq}$. per $\mathrm{L}$. (30). This red cell chloride correction may amount to 5 to 10 per cent of the total whole muscle chloride.

The nitrogen content of whole blood is an appreciable amount of the total NCN in whole muscle. This correction is obtained by multiplying the average whole blood volume of $9.09 \mathrm{ml}$. per $100 \mathrm{Gm}$. of muscle by the concentration of nitrogen found in the peripheral blood, and this may amount to 5 to 10 per cent of the total whole muscle NCN.

In the calculations, the Gibbs-Donnan factors tabu- 
lated by Manery (19, pp. 349-350) were employed, and the factor of 0.977 appears below in the expression for the chloride space. In general, only sodium required an allowance for its extracellular location, and it has been used in the sample calculations below. For potassium, magnesium, and phosphorus the total amount present in wet fat-free muscle was usually employed where $(\mathrm{Na})_{\text {Io }}$ appears in the third part of the following calculations :

\section{Analytical values}

Whole wet muscle

$\left(\mathrm{H}_{2} \mathrm{O}\right)_{m}=$ Per cent of water by weight

$(\text { Fat })_{m}=$ Per cent of fat by weight

$(\mathrm{Na})_{\mathrm{m}},(\mathrm{K})_{\mathrm{m}},(\mathrm{Mg})_{\mathrm{m}}$, and $(\mathrm{Cl})_{\mathrm{m}}=\mathrm{mEq}$. per $100 \mathrm{Gm}$.

$(P)_{m}=m M$ per $100 \mathrm{Gm}$.

$(\mathrm{NCN})_{m}=\mathrm{Gm}$. per $100 \mathrm{Gm}$.

\section{Blood or serum}

$\left(\mathrm{H}_{2} \mathrm{O}\right)_{2}=\mathrm{Gm}$. per $100 \mathrm{ml}$. serum

$(\mathrm{Na})_{a,}(\mathrm{~K})_{B},(\mathrm{Mg})_{B}$, and $(\mathrm{Cl})_{s}=\mathrm{mEq}$. per L. serum

$(\mathrm{N})_{b}=\mathrm{Gm}$. per $100 \mathrm{ml}$. whole blood

$(\mathrm{Hct})_{b}=$ Hematocrit in per cent

Factor converting whole wet muscle values to wet fatfree muscle values:

$$
\frac{100}{100-(\text { Fat })_{m}}
$$

Factor converting values per liter of serum to values per kilogram of serum water :

$$
\frac{100}{\left(\mathrm{H}_{2} \mathrm{O}\right)}
$$

2. Derived values of chloride space, intracellular water, and corrected NCN

Chloride in red cells (in mEq. per $100 \mathrm{Gm}$. of wet fatfree muscle):

$$
(\mathrm{Cl})_{\mathrm{RC}}=4.09 \times \frac{(\mathrm{Hct})_{\mathrm{b}}}{45} \times \frac{50}{1,000}
$$

Chloride space (in $\mathrm{Gm} . \mathrm{H}_{2} \mathrm{O}$ per $100 \mathrm{Gm}$. wet fat-free muscle):

$$
\text { (Cl) Space }=\frac{(\mathrm{Cl})_{m} \times \frac{100}{100-(\mathrm{Fat})_{\mathrm{m}}}-(\mathrm{Cl})_{\mathrm{RC}}}{\frac{(\mathrm{Cl})_{\mathrm{g}}}{0.977} \times \frac{100}{\left(\mathrm{H}_{2} \mathrm{O}\right)_{\mathrm{g}}} \times \frac{1}{1,000}}
$$

Intracellular water (in $\mathrm{Gm}$. per $100 \mathrm{Gm}$. wet fat-free muscle) :

$$
\left(\mathrm{H}_{2} \mathrm{O}\right)_{\mathrm{IC}}=\left(\mathrm{H}_{2} \mathrm{O}\right)_{\mathrm{m}} \times \frac{100}{100-(\text { Fat })_{m}}-\mathrm{Cl} \text { space }
$$

Nitrogen in whole blood (in $\mathrm{Gm}$. per $100 \mathrm{Gm}$. wet fatfree muscle):

$$
9.09 \times \frac{(\mathrm{N})_{\mathrm{b}}}{100}
$$

Corrected NCN (in $\mathrm{Gm}$. per $100 \mathrm{Gm}$. wet fat-free muscle):

$$
(\mathrm{NCN})_{0}=(\mathrm{NCN})_{\mathrm{m}} \times \frac{100}{100-(\mathrm{Fat})_{\mathrm{m}}}-9.09 \times \frac{(\mathrm{N})_{\mathrm{b}}}{100}
$$

3. Derived values of intracellular sodium, potassium, magnesium, and phosphorus

(Sodium used as an example of the allowance necessary for the extracellular location. For the other intracellular components the total amount present in wet fat-free muscle was usually employed where ( $\mathrm{Na})_{\mathrm{rc}}$ appears below.)

Extracellular sodium (in $\mathrm{mEq}$. per $\mathrm{Gm}$. wet fat-free muscle):

$$
\begin{aligned}
(\mathrm{Na})_{E C}=\frac{(\mathrm{Na})_{\mathrm{B}}}{1,000} & \times \frac{100}{\left(\mathrm{H}_{2} \mathrm{O}\right)_{\mathrm{B}}} \\
& \times \text { Gibbs-Donnan factor } \times \mathrm{Cl} \text { space }
\end{aligned}
$$

Intracellular sodium:

In $\mathrm{mEq}$. per $100 \mathrm{Gm}$. wet fat-free muscle :

$$
(\mathrm{Na})_{\mathrm{IC}}=(\mathrm{Na})_{m} \times \frac{100}{100-(\text { Fat })_{m}}-(\mathrm{Na})_{\mathrm{EC}}
$$

In $\mathrm{mEq}$. per $\mathrm{Kg}$. intracellular water :

$$
(\mathrm{Na})_{\mathrm{IC}} \times \frac{1,000}{\left(\mathrm{H}_{2} \mathrm{O}\right)_{\mathrm{IC}}}
$$

In mEq. per $\mathrm{Gm}$. intracellular NCN :

$$
(\mathrm{Na})_{\mathrm{Ic}} \times \frac{1}{(\mathrm{NCN})_{0}}
$$

\section{RESULTS}

\section{Analytical data}

In establishing the values of the components in normal muscle, the ten patients listed in Table I had two samples of grossly normal muscle removed from the excised surgical specimen. These twenty samples were analyzed in replicate for sodium, potassium, magnesium, phosphorus, chloride, and nitrogen. The fat and water content were determined by one analysis apiece in each sample. Except for the fat and water content, the muscle data in Table II are mean values of the replicate muscle sample analyses. These results are expressed directly per 100 grams of wet fatfree muscle except for the values of the fat which are expressed per 100 grams of whole muscle. These analyses establish the normal values of muscle in this study and provide the basic data from which the derived values are computed. Only one blood sample was obtained in conjunction with each patient, and the mineral, nitrogen, and hematocrit determinations were applied to both muscle samples. The precision of the method is reviewed in the following analysis of variance of the muscle data in Table II. 
TABLE I

Patients providing control muscle samples

\begin{tabular}{|c|c|c|c|c|c|c|}
\hline Patient & Unit number & Age & Sex & Diagnosis & Anesthesia & Muscle \\
\hline 1 & 902921 & 61 & $\mathbf{F}$ & $\mathrm{Ca}$ & GOE & Pectoralis, \\
\hline 2 & 862781 & 42 & $\mathbf{F}$ & $\begin{array}{l}\text { breast } \\
\text { Ca }\end{array}$ & GOE & $\begin{array}{l}\text { uninvolved in ca } \\
\text { Pectoralis, }\end{array}$ \\
\hline 3 & 680668 & 80 & $\mathbf{M}$ & thyroid & GOE & $\begin{array}{c}\text { Sternocleidomastoideus, } \\
\text { uninvolved in ca }\end{array}$ \\
\hline 4 & 404794 & 79 & $\mathbf{M}$ & $\underset{\text { mouth }}{\mathrm{Ca}}$ & GOE & $\begin{array}{l}\text { Sternocleidomastoideus, } \\
\text { uninvolved in ca }\end{array}$ \\
\hline 5 & 706130 & 51 & $\mathbf{M}$ & $\begin{array}{l}\text { Arterial insufficiency, } \\
\text { distal foot }\end{array}$ & Spinal & $\begin{array}{l}\text { Semitendinosus } \\
\text { and biceps femoris }\end{array}$ \\
\hline 6 & 338429 & 81 & $\mathbf{F}$ & $\begin{array}{l}\text { Arterial insufficiency, } \\
\text { distal foot }\end{array}$ & Spinal & $\begin{array}{l}\text { Gastrocnemius and } \\
\text { soleus }\end{array}$ \\
\hline 7 & 602894 & 71 & $\mathbf{F}$ & $\begin{array}{l}\text { Arterial insufficiency, } \\
\text { distal foot }\end{array}$ & Spinal & $\begin{array}{l}\text { Semitendinosus } \\
\text { and biceps femoris }\end{array}$ \\
\hline 8 & 6194 & 50 & $\mathbf{F}$ & $\begin{array}{l}\text { Diabetic gangrene, } \\
\text { distal foot; diabetes } \\
\text { compensated }\end{array}$ & Spinal & $\begin{array}{l}\text { Gastrocnemius and } \\
\text { soleus }\end{array}$ \\
\hline 9 & 906321 & 77 & $\mathbf{M}$ & $\begin{array}{l}\text { Diabetic gangrene, } \\
\text { distal foot; diabetes } \\
\text { compensated }\end{array}$ & Spinal & $\begin{array}{l}\text { Semitendinosus } \\
\text { and biceps femoris }\end{array}$ \\
\hline 10 & 866726 & 70 & $\mathrm{~F}$ & $\begin{array}{l}\text { Diabetic gangrene, } \\
\text { distal foot; diabetes } \\
\text { compensated }\end{array}$ & Spinal & $\begin{array}{l}\text { Semitendinosus } \\
\text { and biceps femoris }\end{array}$ \\
\hline
\end{tabular}

\section{Analysis of variance of the analytical data}

To account for the range of values of any muscle component noted by inspection in Table II, three separate sources of variation may be identified. The over-all variation is the net effect of variation introduced by 1) differences inherent in the composition of muscle between individual patients, 2) a lack of similarity in the two muscle samples obtained from a single patient, and 3) discrepancies in the analytical techniques. Since the first source of variation is the only one of clinical interest, it is necessary to assign to each

TABLE II

Analytical values of 10 control patients

\begin{tabular}{|c|c|c|c|c|c|c|c|c|c|c|c|c|c|}
\hline \multirow[b]{2}{*}{ Patient } & \multirow{2}{*}{$\begin{array}{l}\text { Muscle } \\
\text { sample }\end{array}$} & \multicolumn{7}{|c|}{ Per $100 \mathrm{Gm}$. wet fat-free muscle } & \multirow{2}{*}{$\begin{array}{c}\begin{array}{c}\text { Whole } \\
\text { muscle }\end{array} \\
\text { Fat }\end{array}$} & \multicolumn{2}{|c|}{ Per Kg. serum water } & \multicolumn{2}{|c|}{ Whole blood } \\
\hline & & $\mathrm{Na}$ & $\mathbf{K}$ & $\mathbf{M g}$ & $\mathbf{P}$ & $\mathrm{Cl}$ & $\mathrm{NCN}$ & $\mathrm{H}_{2} \mathrm{O}$ & & $\mathbf{N a}$ & $\mathrm{Cl}$ & $\mathbf{N}$ & Hct. \\
\hline & & $m E q$. & $m E q$ & $m E q$ & $m M$ & $m E q$ & $G m$ & Gm. & $\begin{array}{c}\mathrm{Gm} . / \\
100 \mathrm{Gm} .\end{array}$ & $m E q$ & $m E q$ & $\begin{array}{c}G m . / \\
100 \mathrm{ml} .\end{array}$ & $\%$ \\
\hline 1 & II & $\begin{array}{l}2.63 \\
2.93\end{array}$ & $\begin{array}{l}\mathbf{8 . 5 1} \\
8.58\end{array}$ & $\begin{array}{l}1.40 \\
1.56\end{array}$ & $\begin{array}{l}5.18 \\
5.25\end{array}$ & $\begin{array}{l}1.71 \\
1.96\end{array}$ & $\begin{array}{l}2.49 \\
2.52\end{array}$ & $\begin{array}{l}80.2 \\
78.1\end{array}$ & $\begin{array}{l}5.28 \\
5.47\end{array}$ & 149 & 112 & 3.11 & 32.7 \\
\hline 2 & & $\begin{array}{l}3.12 \\
2.92\end{array}$ & $\begin{array}{l}9.87 \\
9.87\end{array}$ & $\begin{array}{l}1.70 \\
1.59\end{array}$ & $\begin{array}{l}6.05 \\
5.87\end{array}$ & $\begin{array}{l}1.51 \\
1.39\end{array}$ & $\begin{array}{l}2.97 \\
2.88\end{array}$ & $\begin{array}{l}79.0 \\
78.4\end{array}$ & $\begin{array}{l}2.10 \\
1.56\end{array}$ & 150 & 111 & 2.88 & 30.9 \\
\hline 3 & & $\begin{array}{l}3.82 \\
3.24\end{array}$ & $\begin{array}{l}9.25 \\
9.40\end{array}$ & $\begin{array}{l}1.57 \\
1.33\end{array}$ & $\begin{array}{l}4.91 \\
5.15\end{array}$ & $\begin{array}{l}2.29 \\
1.82\end{array}$ & $\begin{array}{l}2.31 \\
2.53\end{array}$ & $\begin{array}{l}81.0 \\
80.0\end{array}$ & $\begin{array}{l}1.30 \\
1.10\end{array}$ & 151 & 110 & 2.80 & $30.0^{*}$ \\
\hline 4 & & $\begin{array}{l}2.92 \\
3.50\end{array}$ & $\begin{array}{r}10.06 \\
9.74\end{array}$ & $\begin{array}{l}1.69 \\
1.71\end{array}$ & $\begin{array}{l}5.29 \\
5.34\end{array}$ & $\begin{array}{l}1.76 \\
2.15\end{array}$ & $\begin{array}{l}3.03 \\
2.92\end{array}$ & $\begin{array}{l}78.8 \\
79.0\end{array}$ & $\begin{array}{r}1.19 \\
1.46\end{array}$ & 146 & 113 & 2.99 & 27.8 \\
\hline 5 & & $\begin{array}{l}5.33 \\
5.08\end{array}$ & $\begin{array}{l}7.95 \\
8.23\end{array}$ & $\begin{array}{l}1.79 \\
1.66\end{array}$ & $\begin{array}{l}5.97 \\
6.37\end{array}$ & $\begin{array}{l}3.12 \\
3.12\end{array}$ & $\begin{array}{l}2.46 \\
2.45\end{array}$ & $\begin{array}{l}80.5 \\
80.5\end{array}$ & $\begin{array}{l}18.3 \\
18.5\end{array}$ & 148 & 114 & 2.89 & 30.7 \\
\hline 6 & & $\begin{array}{l}5.28 \\
5.36\end{array}$ & $\begin{array}{r}9.56 \\
9.86\end{array}$ & 2.13 & $\begin{array}{l}5.74 \\
6.10\end{array}$ & $\begin{array}{l}2.10 \\
2.23\end{array}$ & $\begin{array}{l}2.56 \\
2.73\end{array}$ & $\begin{array}{l}80.2 \\
83.5\end{array}$ & $\begin{array}{l}19.6 \\
22.3\end{array}$ & 169 & 102 & 3.11 & 43.1 \\
\hline 7 & II & $\begin{array}{l}4.66 \\
5.18\end{array}$ & $\begin{array}{l}9.40 \\
9.05\end{array}$ & $\begin{array}{l}1.60 \\
1.53\end{array}$ & $\begin{array}{l}5.18 \\
5.12\end{array}$ & $\begin{array}{l}1.95 \\
2.38\end{array}$ & $\begin{array}{l}2.63 \\
2.54\end{array}$ & $\begin{array}{l}79.8 \\
79.8\end{array}$ & $\begin{array}{l}2.70 \\
3.40\end{array}$ & 147 & 108 & 3.12 & 44.3 \\
\hline 8 & II & $\begin{array}{l}5.65 \\
4.90\end{array}$ & $\begin{array}{l}7.34 \\
8.06\end{array}$ & $\begin{array}{l}1.17 \\
1.25\end{array}$ & $\begin{array}{l}4.13 \\
4.79\end{array}$ & $\begin{array}{l}3.91 \\
3.16\end{array}$ & $\begin{array}{l}2.17 \\
2.41\end{array}$ & $\begin{array}{l}85.0 \\
82.0\end{array}$ & $\begin{array}{l}4.61 \\
5.18\end{array}$ & 168 & 109 & 2.70 & 25.2 \\
\hline 9 & II & $\begin{array}{l}5.22 \\
4.97\end{array}$ & $\begin{array}{r}8.75 \\
8.91\end{array}$ & $\begin{array}{l}1.66 \\
1.86\end{array}$ & $\begin{array}{l}4.84 \\
5.04\end{array}$ & $\begin{array}{l}2.45 \\
2.32\end{array}$ & $\begin{array}{l}2.18 \\
2.41\end{array}$ & $\begin{array}{l}80.0 \\
80.0\end{array}$ & $\begin{array}{r}4.10 \\
5.70\end{array}$ & 140 & 98.6 & 2.74 & 36.8 \\
\hline 10 & II & $\begin{array}{l}5.45 \\
5.07\end{array}$ & $\begin{array}{r}10.6 \\
9.58\end{array}$ & $\begin{array}{l}1.70 \\
1.49\end{array}$ & $\begin{array}{l}5.67 \\
5.42\end{array}$ & $\begin{array}{l}2.44 \\
2.34\end{array}$ & $\begin{array}{l}2.75 \\
2.59\end{array}$ & $\begin{array}{l}80.4 \\
79.6\end{array}$ & $\begin{array}{r}12.3 \\
7.7\end{array}$ & 146 & 100 & 2.82 & 37.1 \\
\hline
\end{tabular}

* Assumed value. 
TABLE III

Analysis of variance of analytical values

\begin{tabular}{|c|c|c|c|c|c|c|c|c|c|}
\hline$\underset{\text { nent** }}{\stackrel{1}{1}}$ & $\begin{array}{c}2 \\
\text { Source of } \\
\text { variation }\end{array}$ & $\begin{array}{c}3 \\
\text { Degrees of } \\
\text { freedom }\end{array}$ & $\underset{\text { squares }}{\stackrel{4}{4}}$ & $\begin{array}{c}5 \\
\text { Mean } \\
\text { square }\end{array}$ & $\begin{array}{c}6 \\
\text { Analyses per } \\
\text { subclase }\end{array}$ & $\begin{array}{c}7 \\
\text { Variance }\end{array}$ & $\begin{array}{c}8 \\
\text { Standard } \\
\text { deviation }\end{array}$ & $\begin{array}{c}9 \\
\text { Mean of } \\
\text { patients }\end{array}$ & $\begin{array}{l}10 \\
\text { Coefficient } \\
\text { of variation }\end{array}$ \\
\hline \multirow[t]{2}{*}{$\mathrm{Na}$} & $\begin{array}{l}\text { Patients } \\
\text { Samples } \\
\text { Analyses }\end{array}$ & $\begin{array}{r}9 \\
10 \\
39\end{array}$ & $\begin{array}{r}61.9824 \\
2.9981 \\
0.0054\end{array}$ & $\begin{array}{l}6.8869 \dagger \\
0.2998 \dagger \\
0.0001\end{array}$ & $\begin{array}{l}5.90 \\
2.95 \\
1.00\end{array}$ & $\begin{array}{l}1.116 \\
0.102 \\
0.000\end{array}$ & & & $\%$ \\
\hline & Totals & 58 & 64.9859 & & & 1.218 & 1.10 & 4.36 & 25 \\
\hline \multirow[t]{2}{*}{$\mathbf{K}$} & $\begin{array}{l}\text { Patients } \\
\text { Samples } \\
\text { Analyses }\end{array}$ & $\begin{array}{r}9 \\
10 \\
40\end{array}$ & $\begin{array}{r}33.3274 \\
4.5117 \\
0.0416\end{array}$ & $\begin{array}{l}3.7030 \dagger \\
0.4512 \dagger \\
0.0010\end{array}$ & $\begin{array}{l}6.00 \\
3.00 \\
1.00\end{array}$ & $\begin{array}{l}0.542 \\
0.150 \\
0.001\end{array}$ & & 、 & \\
\hline & Totals & 59 & 37.8807 & & & 0.693 & 0.832 & 9.13 & 9.1 \\
\hline \multirow[t]{2}{*}{$\mathbf{M g}$} & $\begin{array}{l}\text { Patients } \\
\text { Samples } \\
\text { Analyses }\end{array}$ & $\begin{array}{r}9 \\
10 \\
60\end{array}$ & $\begin{array}{l}3.8160 \\
0.5849 \\
0.0891\end{array}$ & $\begin{array}{l}0.4240 \dagger \\
0.0585 \dagger \\
0.0015\end{array}$ & $\begin{array}{l}7.99 \\
4.00 \\
1.00\end{array}$ & $\begin{array}{l}0.0457 \\
0.0143 \\
0.0015\end{array}$ & & & \\
\hline & Totals & 79 & 4.4900 & & & 0.0615 & 0.248 & 1.63 & 15 \\
\hline \multirow[t]{2}{*}{$\mathrm{Cl}$} & $\begin{array}{l}\text { Patients } \\
\text { Samples } \\
\text { Analyses }\end{array}$ & $\begin{array}{r}9 \\
10 \\
58\end{array}$ & $\begin{array}{r}27.4471 \\
2.4010 \\
0.2839\end{array}$ & $\begin{array}{l}3.0497 \dagger \\
0.2401 \dagger \\
0.0049\end{array}$ & $\begin{array}{l}7.80 \\
3.90 \\
1.00\end{array}$ & $\begin{array}{l}0.360 \\
0.060 \\
0.005\end{array}$ & & & \\
\hline & Totals & 77 & 30.1320 & . & & 0.425 & 0.652 & 2.31 & 28 \\
\hline \multirow[t]{2}{*}{$P$} & $\begin{array}{l}\text { Patients } \\
\text { Samples } \\
\text { Analyses }\end{array}$ & $\begin{array}{r}9 \\
10 \\
54\end{array}$ & $\begin{array}{r}19.254 \\
2.061 \\
5.442\end{array}$ & $\begin{array}{l}2.139 \dagger \\
0.206 \ddagger \\
0.101\end{array}$ & $\begin{array}{l}7.33 \\
3.68 \\
1.00\end{array}$ & $\begin{array}{l}0.264 \\
0.029 \\
0.101\end{array}$ & & & \\
\hline & Totals & 73 & 26.757 & & & 0.394 & 0.628 & 5.37 & 12 \\
\hline \multirow[t]{2}{*}{$\mathrm{NCN}$} & $\begin{array}{l}\text { Patients } \\
\text { Samples } \\
\text { Analyses }\end{array}$ & $\begin{array}{r}9 \\
10 \\
33\end{array}$ & $\begin{array}{l}2.7742 \\
0.2904 \\
0.0458\end{array}$ & $\begin{array}{l}0.3082 \dagger \\
0.0290 \dagger \\
0.0014\end{array}$ & $\begin{array}{l}5.29 \\
2.76 \\
1.00\end{array}$ & $\begin{array}{l}0.0528 \\
0.0100 \\
0.0014\end{array}$ & & & \\
\hline & Totals & 52 & 3.1104 & & & 0.0642 & 0.253 & 2.58 & 9.8 \\
\hline \multirow[t]{2}{*}{$\mathrm{H}_{2} \mathrm{O}$} & $\begin{array}{l}\text { Patients } \\
\text { Samples } \\
\text { Analyses }\end{array}$ & $\begin{array}{r}9 \\
10\end{array}$ & $\begin{array}{l}44.92 \\
11.09\end{array}$ & $\begin{array}{l}4.99 \dagger \\
0.11\end{array}$ & $\begin{array}{l}2.00 \\
1.00\end{array}$ & $\begin{array}{l}2.44 \\
0.11\end{array}$ & & & \\
\hline & Totals & 19 & 56.01 & & & 2.55 & 1.60 & 80.3 & 2.0 \\
\hline \multirow[t]{2}{*}{ Fat } & $\begin{array}{l}\text { Patients } \\
\text { Samples } \\
\text { Analyses }\end{array}$ & $\begin{array}{r}9 \\
10\end{array}$ & $\begin{array}{r}905.9536 \\
16.1303\end{array}$ & $\begin{array}{c}100.66 \dagger \\
1.61\end{array}$ & $\begin{array}{l}2.00 \\
1.00\end{array}$ & $\begin{array}{r}49.5 \\
1.6\end{array}$ & & & \\
\hline & Totals & 19 & 922.0839 & & & 51.1 & 7.15 & 7.19 & 99 \\
\hline
\end{tabular}

* $\mathrm{Na}, \mathrm{K}, \mathrm{Mg}$, and $\mathrm{Cl}$ are expressed in $\mathrm{mEq}$; $\mathrm{P}$ in $\mathrm{mM}$; and $\mathrm{H}_{2} \mathrm{O}$ and $\mathrm{NCN}$ are expressed in $\mathrm{Gm}$., all per $100 \mathrm{Gm}$ wet fat-free muscle. Fat is stated in $\mathrm{Gm}$. per $100 \mathrm{Gm}$. whole wet muscle.

$\dagger$ The mean square ratio, $F$, reveals a probability of less than 1 per cent that these variations in the analyses or samples can account for the greater variation in the samples or patients respectively by random sampling.

$\ddagger$ The mean square ratio, $F$, reveals a probability of less than 5 per cent.

source its contribution to the total variation so that the differences noted in Table II are demonstrated to be not merely an accident of the complex analytical techniques or merely a result of random sampling of non-uniform skeletal muscle.

Table III presents the outline of the analysis of variance of the data following the principles of
R. A. Fisher (31) and the details of the treatment by Snedecor (32). To conserve space the individual determinations have not been tabulated separately, and the sample means have already been presented in Table II. For example, the sodium data in Table III are based on 59 sodium analyses performed on twenty muscle samples 
from ten patients. The two averages of the individual analyses for sodium in the two muscle samples obtained from Patient 1 are 2.63 and 2.93 according to Table II. The data in Table III on fat and water do not have their variation partitioned into three sources inasmuch as replicate analyses were not done. The first six columns contain the statistics on which is based the computation of the variance tabulated in Column 7 . The variance totalled for each component in Column 7 is that of a single analysis in one sample from one patient. This variance is the appropriate one to determine the significance of subsequent analyses in diseased states that must perforce be based on less material than in these replicate studies. The standard deviations in Column 8 likewise are those to be assigned to a mean obtained from a series of patients providing one muscle sample each, on which only one analysis for a particular component is carried out. In short, the computed standard deviations have been corrected for the replications in the control data. In Column 9 are recorded the patient means which are calculated from the muscle data in Table II. The coefficient of variation in Column 10 will be considered in connection with the comparison of different reference bases.

As indicated in the footnote of Table III, the ratios of the mean squares tabulated in Column 5 reveal the highly probable circumstance that in all the determinations the variation of the analytical methods is not responsible for the variation in the samples and that the variation of the samples is not responsible for the variation in the patients. Indeed the variation introduced by the chemical methods employed is so slight in comparison to the main sources of variation from the muscle samples and patients that in the subsequent discussion of the derived data only the means of the sample analyses were employed in the calculations. We conclude that in every instance the analytical

TABLE IV

Derived values of 10 control patients

\begin{tabular}{|c|c|c|c|c|c|c|c|c|c|c|c|}
\hline \multirow[b]{2}{*}{ Patient } & \multirow[b]{2}{*}{ Sample } & \multicolumn{5}{|c|}{ Per Kg. intracellular $\mathrm{H}_{2} \mathrm{O}$} & \multicolumn{5}{|c|}{ Per Gm. NCN† } \\
\hline & & $\mathrm{Na}^{*}$ & $\mathbf{K}$ & Mg & $\mathbf{P}$ & $\mathrm{NCN \dagger}$ & $\mathrm{Na}^{*}$ & $\mathbf{K}$ & $\mathbf{M g}$ & $\mathbf{P}$ & $\mathrm{H}_{2} \mathrm{O} \neq$ \\
\hline $\begin{array}{r}1 \\
2 \\
3 \\
4 \\
5 \\
6 \\
7 \\
8 \\
9 \\
10\end{array}$ & $\begin{array}{c}\text { I } \\
\text { II } \\
\text { I } \\
\text { II } \\
\text { I } \\
\text { II } \\
\text { I } \\
\text { II } \\
\text { I } \\
\text { II } \\
\text { I } \\
\text { II } \\
\text { I } \\
\text { II } \\
\text { I } \\
\text { II } \\
\text { I } \\
\text { II } \\
\text { I } \\
\text { II }\end{array}$ & $\begin{array}{c}m E q . \\
10.5 \\
11.3 \\
21.8 \\
20.8 \\
18.7 \\
18.2 \\
15.2 \\
17.9 \\
32.4 \\
27.8 \\
38.4 \\
35.4 \\
38.6 \\
40.8 \\
5.48 \\
10.5 \\
42.7 \\
36.5 \\
41.3 \\
37.0\end{array}$ & $\begin{array}{c}m B_{q} \\
128 \\
138 \\
147 \\
146 \\
148 \\
143 \\
156 \\
158 \\
145 \\
150 \\
154 \\
154 \\
147 \\
151 \\
144 \\
145 \\
144 \\
150 \\
182 \\
164\end{array}$ & $\begin{array}{l}m E q . \\
21.2 \\
25.1 \\
25.3 \\
23.6 \\
25.2 \\
20.3 \\
26.2 \\
27.8 \\
32.6 \\
30.2 \\
34.4 \\
33.0 \\
25.0 \\
25.5 \\
22.9 \\
22.5 \\
27.2 \\
31.3 \\
29.3 \\
25.5\end{array}$ & $\begin{array}{c}m M \\
78.0 \\
84.6 \\
89.8 \\
86.8 \\
78.6 \\
78.5 \\
81.9 \\
86.8 \\
109.0 \\
116.0 \\
92.6 \\
95.4 \\
81.0 \\
85.2 \\
81.0 \\
86.4 \\
79.4 \\
84.8 \\
97.5 \\
92.7\end{array}$ & $\begin{array}{l}G m . \\
33.3 \\
36.1 \\
40.2 \\
38.8 \\
33.0 \\
34.8 \\
42.7 \\
43.2 \\
40.0 \\
39.8 \\
36.8 \\
38.3 \\
36.8 \\
37.7 \\
37.6 \\
38.9 \\
31.7 \\
36.4 \\
42.8 \\
39.9\end{array}$ & $\begin{array}{l}m E q . \\
0.317 \\
0.312 \\
0.543 \\
0.538 \\
0.568 \\
0.522 \\
0.355 \\
0.416 \\
0.810 \\
0.695 \\
1.04 \\
0.926 \\
1.05 \\
1.09 \\
0.146 \\
0.268 \\
1.35 \\
1.00 \\
0.964 \\
0.927\end{array}$ & $\begin{array}{l}m E q . \\
3.85 \\
3.83 \\
3.64 \\
3.76 \\
4.48 \\
4.12 \\
3.65 \\
3.68 \\
3.61 \\
3.74 \\
4.18 \\
4.02 \\
4.00 \\
4.00 \\
3.82 \\
3.73 \\
4.53 \\
4.12 \\
4.25 \\
4.11\end{array}$ & $\begin{array}{c}m E q . \\
0.636 \\
0.696 \\
0.629 \\
0.606 \\
0.762 \\
0.583 \\
0.614 \\
0.646 \\
0.814 \\
0.755 \\
0.935 \\
0.863 \\
0.681 \\
0.677 \\
0.610 \\
0.578 \\
0.680 \\
0.862 \\
0.683 \\
0.640\end{array}$ & $\begin{array}{l}m M \\
2.34 \\
2.34 \\
2.23 \\
2.24 \\
2.38 \\
2.26 \\
1.92 \\
2.02 \\
2.71 \\
2.89 \\
2.52 \\
2.49 \\
2.21 \\
2.27 \\
2.15 \\
2.22 \\
2.50 \\
2.33 \\
2.28 \\
2.33\end{array}$ & $\begin{array}{c}G m . \\
30.1 \\
27.7 \\
24.8 \\
25.8 \\
30.3 \\
28.7 \\
23.5 \\
23.2 \\
25.0 \\
25.0 \\
27.2 \\
26.1 \\
27.2 \\
26.6 \\
26.6 \\
25.7 \\
31.5 \\
27.5 \\
23.4 \\
25.0\end{array}$ \\
\hline \multicolumn{2}{|c|}{$\begin{array}{l}\text { Mean } \\
\text { Standard error } \\
\text { Fiducial limits of mean: } \\
\qquad \mathbf{P}=0.90\end{array}$} & $\begin{array}{c}19- \\
33 \\
13- \\
39 \\
12.6 \\
48\end{array}$ & $\begin{array}{c}144- \\
156 \\
139- \\
161 \\
11.0 \\
7.3\end{array}$ & $\begin{array}{c}24- \\
29 \\
23- \\
31 \\
4.06 \\
15\end{array}$ & $\begin{array}{c}82- \\
94 \\
78- \\
99 \\
10.3 \\
12\end{array}$ & $\begin{array}{c}36- \\
40 \\
35- \\
41 \\
3.27 \\
8.6\end{array}$ & $\begin{array}{c}0.49- \\
0.89 \\
0.34- \\
1.05 \\
0.346 \\
50\end{array}$ & $\begin{array}{c}3.8- \\
4.1 \\
3.7- \\
4.3 \\
0.277 \\
7.0\end{array}$ & $\begin{array}{c}0.64- \\
0.77 \\
0.59- \\
0.82 \\
0.110 \\
16\end{array}$ & $\begin{array}{l}2.2- \\
2.5 \\
2.1- \\
2.6 \\
0.223 \\
9.6\end{array}$ & $\begin{array}{c}25- \\
28 \\
24- \\
29 \\
2.35 \\
8.9\end{array}$ \\
\hline
\end{tabular}

* The sodium values have been reduced by the amount in the chloride space.

The NCN has been reduced by the amount of the nitrogen in the vascular space.

I Intracellular water. 
TABLE $\mathbf{V}$

Coefficients of variation of analytical and derived data *

\begin{tabular}{|c|c|c|c|c|c|c|c|c|}
\hline & \multicolumn{8}{|c|}{ Component } \\
\hline & $\mathrm{Na}$ & $\mathbf{K}$ & $\mathbf{M g}$ & $\mathrm{Cl}$ & $P$ & $\mathrm{NCN}$ & $\mathrm{H}_{2} \mathrm{O}$ & Fat \\
\hline $\begin{array}{l}\text { Analytical data } \\
\text { Per } 100 \mathrm{Gm} \text {. wet, fat-free muscle } \\
\text { (Tables II and III) }\end{array}$ & 25 & 9.1 & 15 & 28 & 12 & 9.8 & 2.0 & 99 \\
\hline \multicolumn{9}{|l|}{ Derived data } \\
\hline $\begin{array}{l}\text { Per Kg. intracellular } \mathrm{H}_{2} \mathrm{O} \\
\text { (Table IV) }\end{array}$ & 48 & 7.3 & 15 & & 12 & 8.6 & & \\
\hline $\begin{array}{l}\text { Per Gm. NCN } \\
\text { (Table IV) }\end{array}$ & 50 & 7.0 & 16 & & 9.6 & & 8.9 & \\
\hline $\begin{array}{l}\text { Per } 100 \mathrm{Gm} \text {. dry, fat-free solids } \\
\text { (text) }\end{array}$ & 49 & 10 & 17 & & 11 & & 12 & \\
\hline
\end{tabular}

* All values are $\frac{\text { standard deviation } \times 100}{\text { mean }}$

techniques were sufficiently precise to distinguish between samples and that in each patient the two muscle samples were representative and sufficiently similar to distinguish between the control patients. These conclusions and the calculation of the variance of a series of single analyses on single samples from different patients are indispensable for the future application of the control data.

In this analysis of variance, the possible source of variation based on different muscles in a patient having dissimilar composition has not been considered because the data collected are not extensive enough. If this source of variation exists, it is included here in that attributed to the individual patient.

\section{Derived data}

In Table IV the derived values of the intracellular components are expressed per kilogram of intracellular water and per gram of NCN. At the foot of the Table the mean, standard error, fiducial limits with $P=0.90$ and $P=0.99$, standard deviation, and the coefficient of variation are displayed. The fiducial limits were computed from the $t$-distribution (31), and 9 degrees of freedom were employed because of the comparisons between ten patients. The standard deviation was determined as in Table III, but is based on the duplicate samples from different patients inasmuch as the analytical variation had been shown in Table III to be inconsequential in comparison to that of the samples and patients.

If the data are expressed in terms of $100 \mathrm{Gm}$. dry fat-free solids, the following mean values are obtained : Na, $8.13 \mathrm{mEq}$; $\mathrm{K}, 46.9 \mathrm{mEq}$; $\mathrm{Mg}, 8.36$ mEq.; P, $27.6 \mathrm{mM}$; NCN, 11.9 Gm.; $\mathrm{H}_{2} \mathrm{O}, 314$ $\mathrm{Gm}$. The sodium and water have been corrected for the amount in the chloride space, and the NCN has been corrected for the nitrogen in the vascular space.

The chloride space per $100 \mathrm{Gm}$. wet fat-free muscle has a mean value of $19.3 \mathrm{Gm}$. with a standard deviation of $5.81 \mathrm{Gm}$. and a coefficient of variation of 30 per cent. These values and those in the preceding paragraph may be derived from Table II.

\section{Comparison of reference bases}

A useful statistic for comparing the uniformity in data is the coefficient of variation, and in Table $\mathrm{V}$ are set forth the coefficients assigned to the data expressed in relation to four different reference bases. A desirable characteristic of a reference base is that its use introduces a measure of uniformity in the data consistent with the reference base itself not undergoing wide fluctuations. In Table V the correction for the extracellular sodium to permit a calculation of the intracellular sodium increased the variation in the derived sodium data in comparison to the analytical data. The coefficient of variation of the sodium and chloride in the analytical data and that of the chloride space of 30 per cent are approximately equal because of their sharing a common anatomical compartment. The coefficient of variation for water in the analytical data has the low value of 2 per cent, 
TABLE VI

Tissue analyses from the literature*

\begin{tabular}{|c|c|c|c|c|c|c|c|c|c|}
\hline \multirow[b]{2}{*}{ Author } & \multirow[b]{2}{*}{ Subject } & & \multicolumn{7}{|c|}{ Component per $100 \mathrm{Gm}$. wet, fat-free tissue } \\
\hline & & & $\mathbf{N a}$ & $\mathbf{K}$ & $\mathbf{M g}$ & $\mathbf{P}$ & $\mathrm{Cl}$ & $\mathrm{H}_{2} \mathrm{O}$ & $\mathbf{N}$ \\
\hline Cotlove et al. (33) & Rat & $\begin{array}{l}\text { Mean } \\
\text { S.E. }\end{array}$ & $\begin{array}{c}m E q . \\
2.08 \\
0.04\end{array}$ & $\begin{array}{c}m E q . \\
10.6 \\
0.2\end{array}$ & $\begin{array}{l}m E q . \\
2.23 \\
0.03\end{array}$ & $\begin{array}{r}m M \\
7.68 \\
0.10\end{array}$ & $\begin{array}{l}m E q \\
1.17 \\
0.01\end{array}$ & $\begin{array}{r}G \mathrm{~m} . \\
72.6 \\
0.1\end{array}$ & $\begin{array}{c}\mathrm{Gm} . \\
3.52 \\
0.03\end{array}$ \\
\hline Lilienthal et al. (21) & Rat & $\begin{array}{l}\text { Mean } \\
\text { S.D. }\end{array}$ & & & $\begin{array}{l}2.35 \\
0.18\end{array}$ & $\begin{array}{l}6.97 \\
0.31\end{array}$ & & & $\begin{array}{l}3.33 \dagger \\
0.109\end{array}$ \\
\hline $\begin{array}{l}\text { Hastings and } \\
\text { Eichelberger (20) }\end{array}$ & Dog & $\begin{array}{l}\text { Mean } \\
\text { S.D. }\end{array}$ & $\begin{array}{l}3.24 \\
0.48\end{array}$ & $\begin{array}{l}8.21 \\
1.0\end{array}$ & & & $\begin{array}{l}2.15 \\
0.28\end{array}$ & $\begin{array}{c}76.5 \\
0.64\end{array}$ & \\
\hline Cullen et al. (34) & Man $\ddagger$ & Mean & & 6.29 & 1.51 & 4.84 & 3.13 & 77.4 & \\
\hline Shohl (16) & Man & Mean & 3.1 & 9.3 & 1.9 & 7.1 & 1.8 & 79 & \\
\hline $\begin{array}{l}\text { Mudge and } \\
\text { Vislocky (35) }\end{array}$ & Man & $\left.\begin{array}{l}\text { Range in } \\
3 \text { controls }\end{array}\right\}$ & $\begin{array}{l}3.59- \\
4.42\end{array}$ & $\begin{array}{l}8.19- \\
8.80\end{array}$ & & & $2.74-$ & & $\begin{array}{l}2.93- \\
3.37\end{array}$ \\
\hline Baldwin et al. (23) & Man & $\begin{array}{l}\text { Mean } \\
\text { S.D. }\end{array}$ & & $\begin{array}{l}9.46 \\
1.17\end{array}$ & $\begin{array}{l}1.64 \\
0.21\end{array}$ & $\begin{array}{l}5.90 \\
0.710\end{array}$ & & & $\begin{array}{l}2.70 \dagger \\
0.250\end{array}$ \\
\hline $\begin{array}{l}\text { Barnes, Gordon, } \\
\text { and Cope }\end{array}$ & Man & $\begin{array}{l}\text { Mean } \\
\text { S.D. }\end{array}$ & $\begin{array}{l}4.36 \\
1.10\end{array}$ & $\begin{array}{l}9.13 \\
0.832\end{array}$ & $\begin{array}{l}1.63 \\
0.248\end{array}$ & $\begin{array}{l}5.37 \\
0.628\end{array}$ & $\begin{array}{l}2.31 \\
0.652\end{array}$ & $\begin{array}{c}80.3 \\
1.60\end{array}$ & $\begin{array}{l}2.58 \dagger \\
0.253\end{array}$ \\
\hline
\end{tabular}

* The standard error (S.E.) or standard deviation (S.D.) of the values are stated when given by the authors. They are not strictly comparable because of unstated differences in their computation.

t Value represents NCN.

$\ddagger$ Autopsy material.

and it increases in the derived data because intracellular water is referred to rather than total water. Furthermore, the original expression of the analytical data in terms of the weight of wet tissue inevitably leads to greater uniformity in the water content.

In considering these coefficients of variation it might be supposed that if the results were expressed per kilogram of intracellular water or per gram of non-collagen nitrogen that a greater measure of uniformity might be achieved. Indeed the rationale for introducing these reference bases is founded on the assumption commonly stated, but never proved, that a greater uniformity would appear in the derived results. However, a comparison of the coefficients in Table $\mathrm{V}$ reveals that no striking increase in the uniformity is obtained by expressing the results related to the intracellular water, to the NCN, or to dry solids. Naturally, the fact that no greater uniformity is noted here does not exclude the possibility of more meaningful interpretations of pathological material by employing these same reference bases. This has been substantiated by further experience in diseased states (16).

\section{Comparison of data with other analyses}

The data reported here are in agreement with previous reports in the literature as displayed in Table VI. The close agreement between Baldwin, Robinson, Zierler, and Lilienthal (23), who first applied this method to clinical material, and the data of this paper confirms our impressions of the precision of the methods. The standard deviations as published in various reports are calculated by differing and unstated methods and refer to quantities that are not strictly comparable. However, they serve as a rough guide to the dispersion of the values and indicate that the data of this paper conform to previous tissue analyses.

\section{SUMMARY}

A composite scheme of tissue analysis based on the concepts introduced by A. B. Hastings and J. L. Lilienthal has been presented with details of the analytical methods as applied to skeletal muscle. The outline of the calculations for the derived values of the concentrations of sodium, potassium, magnesium, phosphorus, water, and non-collagen nitrogen is given. These concentra- 
tions are referred to intracellular water derived by means of the chloride space and to the noncollagen nitrogen content of skeletal muscle.

Analytical and derived values from a control series of analyses from ten patients are reported together with a statistical evaluation of the results. Various reference bases are considered in regard to their property to diminish the dispersion of the data, and the similarity of the results with other tissue analyses is discussed.

\section{ACKNOWLEDGMENTS}

The authors are especially grateful to Dr. Frederick Mosteller, Department of Social Relations, Harvard University, who has kindly reviewed the statistical arguments and tables.

The technical help of E. M. Horblit, R. Moore, H. Filipak, and G. G. Eddison has been invaluable in the completion of this study.

\section{REFERENCES}

1. Hirschfelder, A. D., and Haury, V. G., Clinical manifestations of high and low plasma magnesium. Dangers of epsom salt purgation in nephritis. J. A. M. A., 1934, 102, 1138.

2. Hirschfelder, A. D., and Haury, V. G., Variations in plasma magnesium and potassium in epilepsy. Proc. Soc. Exper. Biol. \& Med., 1935, 33, 40.

3. Brookfield, R. W., The magnesium content of serum in renal insufficiency. Quart. J. Med., 1937, N.S. 6, 87.

4. Hirschfelder, A. D., and Haury, V. G., Variations in magnesium and potassium associated with essential epilepsy. Arch. Neurol. \& Psychiat., 1938, $40,66$.

5. Haury, V. G., and Cantarow, A., Variations of serum magnesium in 52 normal and 440 pathologic patients. J. Lab. \& Clin. Med., 1942, 27, 616.

6. Haury, V. G., Variations in serum magnesium in health and disease: A review. J. Lab. \& Clin. Med., 1942, 27, 1361.

7. Dine, R. F., and Lavietes, P. H., Serum magnesium in thyroid disease. J. Clin. Invest., 1942, 21, 781.

8. Martin, H. E., and Wertman, M., Serum potassium, magnesium, and calcium levels in diabetic acidosis. J. Clin. Invest., 1947, 26, 217.

9. Edmondson, H. A., Berne, C. J., Homann, R. E., Jr., and Wertman, M., Calcium, potassium, magnesium and amylase disturbances in acute pancreatitis. Am. J. Med., 1952, 12, 34.

10. Stutzman, F. L., and Amatuzio, D. S., Blood serum magnesium in portal cirrhosis and diabetes mellitus. J. Lab. \& Clin. Med., 1953, 41, 215.
11. Flink, E. B., Magnesium deficiency syndrome in man. J. A. M. A., 1956, 160, 1406.

12. Bulger, H. A., and Gausmann, F., Magnesium metabolism in hyperparathyroidism. J. Clin. Invest., 1933, $12,1135$.

13. Tibbetts, D. M., and Aub, J. C., Magnesium metabolism in health and disease. I. The magnesium and calcium excretion of normal individuals, also the effects of magnesium, chloride, and phosphate ions. J. Clin. Invest., 1937, 16, 491.

14. Tibbetts, D. M., and Aub, J. C., Magnesium metabolism in health and disease. II. The effect of the parathyroid hormone. J. Clin. Invest., 1937, 16, 503.

15. Tibbetts, D. M., and Aub, J. C., Magnesium metabolism in health and disease. III. In exophthalmic goiter, basophilic adenoma, Addison's disease and steatorrhea. J. Clin. Invest., 1937, 16, 511.

16. Shohl, A. T., Mineral metabolism. Am. Chem. Soc. Monograph series 82. New York, Reinholt Publishing Co., 1939.

17. Edelman, I. S., Olney, J. M., James, A. H., Brooks, L., and Moore, F. D., Body composition. Studies in the human being by the dilution principle. Science, 1952, 115, 447.

18. Barnes, B. A., and Cope, O., Skeletal muscle analyses in health and in certain metabolic disorders. II. Determinations in disease, In preparation.

19. Manery, J. F., Water and electrolyte metabolism. Physiol. Rev., 1954, 34, 334.

20. Hastings, A. B., and Eichelberger, L., The exchange of salt and water between muscle and blood. I. The effect of an increase in total body water produced by the intravenous injection of isotonic salt solutions. J. Biol. Chem., 1937, 117, 73.

21. Lilienthal, J. L., Jr., Zierler, K. L., Folk, B. P., Buka, R., and Riley, M. J., A reference base and system for analysis of muscle constituents. J. Biol. Chem., 1950, 182, 501.

22. Lowry, O. H., Gilligan, D. R., and Katersky, E. M., The determination of collagen and elastin in tissues with results obtained in various normal tissues from different species. J. Biol. Chem., 1941, 139, 795.

23. Baldwin, D., Robinson, P. K., Zierler, K. L., and Lilienthal, J. L., Jr., Interrelations of magnesium, potassium, phosphorus, and creatine in skeletal muscle of man. J. Clin. Invest., 1952, 31, 850.

24. Peters, J. P., and Van Slyke, D. D., Quantitative Clinical Chemistry. Volume II, Methods. Baltimore, The Williams \& Wilkins Company, 1932, p. 74.

25. Folin, O., Determination of non-protein nitrogen in Laboratory Manual of Biological Chemistry, 5th ed. New York, Appleton-Century, 1934, p. 265.

26. White, J. U., Precision of a simple flame photometer. Anal. Chem., 1952, 24, 394. 
27. Fiske, C. H., and Subbarow, Y., The colorimetric determination of phosphorus. J. Biol. Chem., 1925, 66, 375.

28. Wilson, D. W., and Ball, E. G., A study of the estimation of chloride in blood and serum. J. Biol. Chem., 1928, 79, 221.

29. Garner, R. J., Colorimetric determination of magnesium in plasma or serum by means of titan yellow. Biochem. J., 1946, 40, 828.

30. Rapoport, S., Stevens, C. D., Engel, G. L., Ferris, E. B., and Logan, M., The effect of voluntary overbreathing on the electrolyte equilibrium of arterial blood in man. J. Biol. Chem., 1946, 163, 411.

31. Fisher, R. A., Statistical Methods for Research Worker, 7th ed. Edinburgh, Oliver and Boyd, 1938.
32. Snedecor, G. W., Statistical Methods Applied to Experiments in Agriculture and Biology, 4th ed. Ames, Iowa, The Iowa State College Press, 1946, pp. 236-241.

33. Cotlove, E., Holliday, M. A., Schwartz, R., and Wallace, W. M., Effects of electrolyte depletion and acid-base disturbance on muscle cations. Am. J. Physiol., 1951, 167, 665.

34. Cullen, G. E., Wilkins, W. E., and Harrison, T. R., Electrolytes in human tissue. II. The electrolyte content of hearts and other tissues from cases with various diseases. J. Biol. Chem., 1933, 102, 415.

35. Mudge, G. H., and Vislocky, K., Electrolyte changes in human striated muscle in acidosis and alkalosis. J. Clin. Invest., 1949, 28, 482. 